\title{
Perilaku ibu rumah tangga yang mempunyai balita dan sanitasi dasar rumah dengan kejadian diare pada balita
}

\author{
Retno Arienta Sari ${ }^{*}$, Dyah Wulan Sumekar Rengganis Wardani², Ratna Dewi Puspita Sari ${ }^{3}$
}

\author{
1Mahasiswa Fakultas Kedokteran Universitas Lampung. *Email: retnoarientaar@gmail.com \\ 2Departemen IImu Kedokteran Keluarga, Fakultas Kedokteran Universitas Lampung \\ ${ }^{3}$ Departemen Obstetri dan Ginekologi, Fakultas Kedokteran Universitas Lampung
}

\section{Abstract \\ Mothers' personal and domestic hygiene and diarrhoea incidence in toddlers in Bandar Lampung, Indonesia}

Background: Diarrhea is still the second highest cause of child mortality in the world after pneumonia. Diarrhea is related to various factors. Maternal behavior and environmental sanitation are factors that are highly associated with the occurrence of diarrhea in infants.

Purpose: To determine of the relationship between mother behavior and sanitation with the incident of diarrhea on toddlers in Kangkung Village Bumi Waras District Bandar Lampung City.

Methods: This study was an observational analytic study with cross sectional approach, conducted in Kangkung Village, Bumi Waras District, Bandar Lampung City in October and November 2019. The sample were all toddlers and their mothers and taken with proportional random sampling technique. The research data were collected using the observation checklist method and questionnaire filling, then the data were analyzed using the chi square test.

Results: Finding the proportion of diarrhea incidence was of $29.4 \%$ and without-diarrhea was of $70.6 \%$. The results showed that the mother's hand washing behavior $(p=0.035)$, boiling drinking water $(p=0.036)$ and the availability of clean water $(p=0.049)$ were related to the incidence of diarrhea in toddlers. While the availability of feces disposal $(p=0.078)$, availability of waste disposal $(p=0.068)$ and waste water disposal facilities $(p=1,000)$ are not related to diarrhea.

Conclusion: Obtaining several factors that are closely related to the incidence of diarrhea, with the behavior of the mother such as handwashing habits, provision of drinking water, and the availability of clean water that meets the requirements. While other factors such as the disposal of feces, garbage disposal, and waste water disposal, there have no relationship with the incidence of diarrhea among toddlers.

Suggestion: The need for activities that involve the community from the family level, neighborhood groups to local government supported by the health department, health centers, schools with the aim of changing the behavior of community .

\section{Keywords: Mothers' Personal; Domestic Hygiene; Diarrhoea Incidence; Toddlers}

Pendahuluan: Diare masih menjadi penyebab kematian balita tertinggi kedua di seluruh dunia setelah pneumonia. Penyakit diare berkaitan dengan berbagai faktor. Perilaku ibu dan sanitasi lingkungan menjadi faktor yang sangat terkait dengan kejadia diare pada balita.

Tujuan: Mengetahui hubungan antara perilaku ibu dan sanitasi dengan kejadian diare pada balita di Kelurahan Kangkung, Kecamatan Bumi Waras, Kota Bandar Lampung.

Metode: Penelitian analitik observasional dengan pendekatan cross sectional, dilakukan di Kelurahan Kangkung, Kecamatan Bumi Waras, Kota Bandar Lampung pada bulan Oktober dan November 2019. Sampelnya seluruh balita dan ibunya, diambil dengan Teknik proportional random sampling. Data penelitian dikumpulkan dengan metode checklist observasi dan pengisian lembar angket, kemudian dilakukan analisis data menggunakan uji chi kuadrat.

Hasil: Didapatkan proporsi kejadian diare sebanyak $29,4 \%$ dan yang tidak diare $70,6 \%$. Adapun hubungan faktor-faktor terkaitnya didapatkan; perilaku cuci tangan ibu $(p=0,035)$, memasak air minum $(p=0,036)$ dan ketersediaan air bersih $(p=0,049)$ berhubungan dengan kejadian diare pada balita. Sedangkan ketersediaan 
Perilaku ibu rumah tangga yang mempunyai balita dan sanitasi dasar rumah dengan kejadian diare pada balita

pembuangan tinja $(p=0,078)$, ketersediaan pembuangan sampah $(p=0,068)$ dan sarana pembuangan air limbah $(p=1,000)$ tidak berhubungan dengan diare.

Simpulan: Didapatkan beberapa faktor yang berhubungan erat antara kejadian diare pada balita, dengan perilaku ibunya seperti kebiasaan cuci tangan, penyediaan air minum, dan ketersediaan air bersih yang memenuhi syarat. Sedangkan faktor lainnya seperti pembuangan tinja, pembuangan sampah, dan pembuangan air limbah, tidak didapatkan hubungan dengan kejadian diare pada balita.

SARAN: Perlunya kegiatan yang melibatkan masyarakat dari tingkat keluarga, rukun tetangga sampai pemerintahan desa yang didukung oleh dinas kesehatan, puskesmas, sekolah dengan tujuan merubah perilaku PHBS masyarakat.

\section{Kata Kunci: Perilaku Ibu Rumah Tangga; Balita; Sanitasi Dasar Rumah; Diare Pada Balita}

\section{PENDAHULUAN}

Penyebab kematian balita tertinggi di seluruh dunia adalah pneumonia dan diikuti oleh diare yang menyumbang 526.000 kematian anak pada tahun 2015 , dan $70 \%$ di antaranya berusia di bawah dua tahun. Ada 15 negara dengan jumlah kematian anak akibat pneumonia dan diare tertinggi, termasuk Indonesia dengan angka kematian balita akibat diare mencapai 7.499 jiwa (United Nations Children's Fund, 2016; International Vaccine Access Center, 2018).

Di Indonesia, tahun 2017 angka diare sebesar 7.077.299 kasus dan yang ditangani hanya 4.274.790 $(60,4 \%)$ kasus, Sementara di Provinsi Lampung sebanyak 223.819 kasus dan yang ditangani hanya $142.838 \quad(63,8 \%)$ kasus. Pemerintah daerah melalui dinas kesehatan Provinsi Lampung di tahun 2019 mempunyai rencana strategi untuk penemuan dan penangan diare menjadi 100\% (Kementerian Kesehatan Republik Indonesia, 2018; Dinas Kesehatan Provinsi Lampung, 2019).

Penyakit diare berkaitan erat dengan berbagai faktor penyebab atau faktor predisposisi diare secara tidak langsung seperti; pemberian ASI eksklusif, status gizi, kondisi lingkungan, perilaku hidup bersih dan sehat (PHBS), imunisasi dan sosial ekonomi (Fatmawati, Arbianingsih, \& Musdalifah, 2017). Selain itu, diare pada balita berhubungan erat dengan perilaku ibu. Ibu merupakan orang yang menghabiskan waktu paling banyak dengan anak. Apabila perilaku ibu tidak mendukung kesehatan balita maka besar pengaruhnya terhadap derajat kesehatan balita (Mauliku, \& Wulansari, 2008). Empat dari sepuluh indikator PHBS sebaiknya dilakukan ibu untuk mencegah diare pada anak, antara lain mencuci tangan dengan sabun dan menggunakan air bersih dan menggunakan toilet yang bersih (Faisal, Sriwahyuni, \& Afandhi, 2016).

Sanitasi merupakan salah satu faktor sangat berhubungan erat dengan tingkat kejadian diare. Menurut World Health Organization (WHO), kurangnya akses terhadap sanitasi dasar dan air minum yang bersih dan aman serta higienitas yang buruk merupakan faktor-faktor yang sangat berpengaruh pada kematian balita akibat diare. Di berbagai negara berkembang, masih banyak penduduk yang tidak memiliki jamban dan tidak mempraktikkan kebiasaan cuci tangan dengan sabun (World Health Organization, 2011). Padahal, cuci tangan dengan sabun saja dapat menurunkan 40\% angka kejadian diare (United Nations Children's Fund, 2016).

Indonesia baru memiliki akses sanitasi yang baik sebanyak $61 \%$ tahun 2015 . Lebih dari 50 juta penduduk Indonesia masih melakukan open defecation dan jumlahnya menempati peringkat kedua tertinggi di dunia setelah India. Hal inilah yang dapat mengakibatkan kontaminasi air minum sehingga mudah terjadi diare (World Health Organization, 2017). Menurut kriteria Joint Monitoring Program WHO/UNICEF, akses sanitasi disebut "baik" apabila rumah tangga yang menggunakan fasilitas buang air besar (BAB) milik sendiri (tidak digunakan bersamaan dengan rumah tangga lain), berjenis leher angsa atau plengsengan dan tempat pembuangan akhir tinja jenis tangki septik (Kementerian Kesehatan Republik Indonesia, 2018).

Provinsi Lampung memiliki $88,1 \%$ penduduk yang menggunakan fasilitas $B A B$ milik sendiri. Menurut data Riset Kesehatan Dasar (Riskesdas) 2018, prevalensi kejadian diare pada balita di Indonesia menurun, yaitu dari $18,5 \%$ pada tahun 2013 menjadi 12,3\% tahun 2018. Namun, angka ini masih menjadi urgensi karena target penanganan

Retno Arienta Sari" Mahasiswa Fakultas Kedokteran Universitas Lampung. *Email: retnoarientaar@gmail.com

Dyah Wulan Sumekar Rengganis Wardani ${ }^{2}$ Departemen llmu Kedokteran Keluarga,

Fakultas Kedokteran Universitas Lampung

Ratna Dewi Puspita Sari ${ }^{3}$ Departemen Obstetri dan Ginekologi, Fakultas Kedokteran Universitas Lampung 
Perilaku ibu rumah tangga yang mempunyai balita dan sanitasi dasar rumah dengan kejadian diare pada balita

diare adalah 100\% pada tahun 2019 (Kementerian Kesehatan Republik Indonesia., 2019).

Angka kejadian diare pada balita di Kota Bandar Lampung pada tahun 2017 mencapai 8225 kasus, sedangkan pada tahun 2018 mencapai 6932 kasus. Walaupun angka kejadian diare menurun, namun kasusnya tetap menunjukkan angka yang tinggi. Puskesmas Sukaraja merupakan salah satu Puskesmas yang memiliki angka kejadian diare balita yang tinggi di Kota Bandar Lampung dengan angka kejadian diare sebanyak 334 kasus pada tahun 2017. Pada tahun 2018, Puskesmas Sukaraja Kota Bandar Lampung tetap berada di posisi tertinggi ke empat dengan angka kejadian diare yang meningkat menjadi 337 kasus. Angka kejadian diare pada bulan Januari hingga Agustus 2019 mencapai 324 kasus (Dinas Kesehatan Kota Bandar Lampung, 2019).

Wilayah kerja Puskesmas Sukaraja memiliki lima kelurahan, di mana Kelurahan Kangkung merupakan kelurahan tertinggi yang memiliki angka kejadian diare. Pada tahun 2018, sebanyak $26,72 \%$ balita di Kelurahan Kangkung mengalami diare dengan peningkatan sebesar $6,94 \%$. Sedangkan pada bulan Januari hingga Agustus 2019, angka kejadian diare pada balita di Kelurahan Kangkung meningkat menjadi $39,7 \%$. Hal ini membuktikan bahwa angka kejadian diare pada Kelurahan Kangkung, Kecamatan Bumi Waras, Kota Bandar Lampung terus meningkat (Dinas Kesehatan Kota Bandar Lampung, 2019).

\section{METODE PENELITIAN}

Jenis penelitian analitik observasional dengan pendekatan cross sectional. Penelitian dilakukan di Kelurahan Kangkung, Kecamatan Bumi Waras, Kota Bandar Lampung, dilaksanakan pada bulan Oktober hingga November 2019, dengan surat layak etik dari fakultas Kedokteran Universitas Lampung No.3173/UN26.18/PP.05.02.00/2019. Populasinya seluruh balita, dengan sampel sebesar 102 responden dengan menggunakan teknik proportional random sampling. Variabel terikatnya kejadian diare pada balita, sedangkan variabel bebasnya perilaku cuci tangan ibu, perilaku cara memasak air ibu, ketersediaan air bersih, pembuangan tinja, pembuangan sampah, dan pembuangan air limbah. Cara pengambilan data melalui pengisian kuesioner mengenai perilaku ibu dan observasi yang digunakan dalam bentuk checklist yaitu mengenai mengenai pembuangan tinja, pembuangan sampah, ketersediaan air dan pembuangan air limbah. Data yang telah dikumpulkan dilakukan analisis univariat dan analisis bivariat menggunakan uji chi square.

Retno Arienta Sari" Mahasiswa Fakultas Kedokteran Universitas Lampung. *Email: retnoarientaar@gmail.com Dyah Wulan Sumekar Rengganis Wardani ${ }^{2}$ Departemen llmu Kedokteran Keluarga, 
Perilaku ibu rumah tangga yang mempunyai balita dan sanitasi dasar rumah dengan kejadian diare pada balita

HASIL

Tabel 1. Distribusi Frekuensi Prilaku Keseharian Responden Dan Kejadian Diare Pada Balita N=102

\begin{tabular}{lcc}
\hline Variabel & Frekuensi (f) & Persentase (\%) \\
\hline Perilaku ibu cuci tangan dengan sabun & & \\
Ya & 62 & 60,8 \\
Tidak & 40 & 39,2 \\
Memasak air minum & 77 & 75,5 \\
Ya & 25 & 24,5 \\
Tidak & & \\
Ketersediaan air bersih & 61 & 59,8 \\
Memenuhi syarat & 41 & 40,2 \\
Tidak memenuhi syarat & & \\
Pembuangan tinja & 46 & 45,1 \\
Memenuhi syarat & 56 & 54,9 \\
Tidak memenuhi syarat & & \\
Pembuangan sampah & 50 & 49 \\
Memenuhi syarat & 52 & 51 \\
Tidak memenuhi syarat & & \\
Pembuangan air limbah & 49 & 52 \\
Memenuhi standar & 53 & 48 \\
Tidak memenuhi standar & & \\
Kejadian diare & 30 & 29,4 \\
Ya & 72 & 70,6 \\
Tidak & 102 & 100 \\
Total &
\end{tabular}

Berdasarkan hasil analisis univariat pada variabel perilaku ibu cuci tangan dengan sabun menunjukkan perilaku ibu yang mencuci tangan sebanyak 62 responden atau $60,8 \%$ dan yang tidak 40 responden atau $39,2 \%$. Pada tabel di atas diketahui bahwa sebanyak 77 responden $(75,5 \%)$ memiliki kebiasan memasak air minum dan yang tidak sebesar 25 reponden (24,5\%). Hasil analisis tentang karakteristik responden berdasarkan ketersediaan air bersih diketahui bahwa responden yang memiliki ketersediaan air bersih yang memenuhi syarat sebanyak 61 responden $(59,8 \%)$ dan yang tidak sebesar 41 responden (40,2\%). Pada karakteristik responden berdasarkan pembuangan tinja diketahui bahwa terdapat 56 responden $(54,9 \%)$ yang tidak memenuhi syarat dan sebanyak 46 responden $(45,1 \%)$ memenuhi persyaratan jamban sehat. Karakteristik responden berdasarkan pembuangan sampah menunjukan sebesar 50 responden atau $49 \%$ memiliki tempat pembuangan sampah yang memenuhi syarat dan 52 responden atau $51 \%$ tidak memenuhi syarat. Karakteristik responden berdasarkan pembuangan air limbah diketahui bahwa terdapat 53 responden (52\%) yang tidak memenuhi standar dan sebanyak 49 responden (48\%) memenuhi standar.

Pada tabel di atas menunjukan bahwa sebanyak 30 responden atau $29,4 \%$ menderita diare dan yang tidak menderita diare sebesar 72 reponden atau $70,6 \%$.

Retno Arienta Sari ${ }^{*}$ Mahasiswa Fakultas Kedokteran Universitas Lampung. *Email: retnoarientaar@gmail.com Dyah Wulan Sumekar Rengganis Wardani ${ }^{2}$ Departemen llmu Kedokteran Keluarga,

Fakultas Kedokteran Universitas Lampung

Ratna Dewi Puspita Sari ${ }^{3}$ Departemen Obstetri dan Ginekologi, Fakultas Kedokteran Universitas Lampung 
Perilaku ibu rumah tangga yang mempunyai balita dan sanitasi dasar rumah dengan kejadian diare pada balita

Tabel 2. Hasil Analisis Hubungan Perilaku Ibu Dan Sanitasi Dengan Kejadian Diare Pada Balita

\begin{tabular}{|c|c|c|c|c|c|c|c|}
\hline \multirow{3}{*}{ Variabel } & \multicolumn{4}{|c|}{ Kejadian diare } & \multirow{2}{*}{\multicolumn{2}{|c|}{ Total }} & \multirow{3}{*}{ p-value } \\
\hline & \multicolumn{2}{|c|}{$\mathrm{Ya}$} & \multicolumn{2}{|c|}{ Tidak } & & & \\
\hline & $\mathrm{n}$ & $(\%)$ & $\mathrm{n}$ & $(\%)$ & $\mathrm{N}$ & $(\%)$ & \\
\hline \multicolumn{8}{|l|}{ Perilaku ibu cuci tangan } \\
\hline Tidak & 17 & 42,5 & 23 & 57,5 & 40 & 100 & \multirow{2}{*}{0,035} \\
\hline $\mathrm{Ya}$ & 13 & 21 & 49 & 79 & 62 & 100 & \\
\hline \multicolumn{8}{|l|}{ Memasak air minum } \\
\hline Tidak & 12 & 48 & 13 & 52 & 25 & 100 & \multirow{2}{*}{0,036} \\
\hline $\mathrm{Ya}$ & 18 & 23,4 & 59 & 76,6 & 77 & 100 & \\
\hline \multicolumn{8}{|l|}{ Ketersediaan air bersih } \\
\hline Tidak memenuhi syarat & 17 & 41,5 & 24 & 58,5 & 41 & 100 & \multirow{3}{*}{0,049} \\
\hline Memenuhi syarat & 13 & 21,3 & 48 & 78,7 & 61 & 100 & \\
\hline \multicolumn{7}{|l|}{ Pembuangan tinja } & \\
\hline Tidak memenuhi syarat & 21 & 37,5 & 35 & 62,5 & 56 & 100 & \multirow{2}{*}{0,078} \\
\hline Memenuhi syarat & 9 & 19,6 & 37 & 80,4 & 46 & 100 & \\
\hline \multicolumn{8}{|l|}{ Pembuangan sampah } \\
\hline Tidak memenuhi syarat & 20 & 38,5 & 32 & 61,5 & 52 & 100 & \multirow{3}{*}{0,068} \\
\hline Memenuhi syarat & 10 & 20 & 40 & 80 & 50 & 100 & \\
\hline \multicolumn{7}{|l|}{ Pembuangan air limbah } & \\
\hline Tidak memenuhi syarat & 16 & 30,2 & 37 & 69,8 & 53 & 100 & \multirow{3}{*}{1,000} \\
\hline Memenuhi syarat & 14 & 28,6 & 35 & 71,4 & 49 & 100 & \\
\hline Total & 30 & 29,4 & 72 & 70,6 & 102 & 100 & \\
\hline
\end{tabular}

Berdasarkan hasil analisis bivariat dapat diketahui bahwa balita yang menderita diare lebih banyak (42,5\%) merupakan balita dengan perilaku ibu yang tidak mencuci tangan. Sedangkan balita yang tidak menderita diare paling banyak (79\%) merupakan balita dengan perilaku ibu yang mencuci tangan. Perilaku cuci tangan ibu yang baik dapat menurunkan kejadian diare pada balita. Hasil analisis chi square diperoleh nilai $p=0,035<$ nilai $\mathrm{a}=0,05$ artinya $\mathrm{HO}$ ditolak dan $\mathrm{Ha}$ diterima.

Berdasarkan hasil analisis bivariat dapat diketahui bahwa balita yang menderita diare lebih banyak $(48 \%)$ merupakan balita dengan perilaku ibu yang tidak memasak air minum hingga matang. Sedangkan balita yang tidak menderita diare paling banyak $(76,6 \%)$ merupakan balita dengan perilaku ibu yang memasak air minum hingga matang. Kebiasaan memasak air minum hingga matang dapat menurunkan kejadian diare pada balita. Analisis diperoleh nilai $p=0,036<$ nilai $a=0,05$ artinya $\mathrm{HO}$ ditolak dan $\mathrm{Ha}$ diterima.

Berdasarkan hasil analisis bivariat dapat diketahui bahwa balita yang menderita diare lebih banyak $(41,5 \%)$ merupakan balita dengan ketersediaan air bersih tidak memenuhi syarat. Sedangkan balita yang tidak menderita diare paling banyak (78,7\%) merupakan balita dengan ketersediaan air bersih yang memenuhi syarat. Ketersediaan air bersih yang memenuhi syarat dapat menurunkan kejadian diare pada balita. Hasil analisis diperoleh nilai $p=0,049<$ nilai $a=$ 0,05 artinya $\mathrm{HO}$ ditolak dan $\mathrm{Ha}$ diterima.

Berdasarkan hasil analisis bivariat dapat diketahui bahwa balita yang menderita diare lebih banyak $(37,5 \%)$ merupakan balita dengan ketersediaan pembuangan tinja yang tidak memenuhi syarat. Sedangkan balita yang tidak menderita diare paling banyak $(80,4 \%)$ merupakan balita dengan ketersediaan pembuangan tinja yang memenuhi syarat. Ketersediaan pembuangan tinja yang memenuhi syarat dapat menurunkan angka kejadian diare pada balita. Hasil analisis diperoleh nilai $p=0,078>$ nilai $a=0,05$. Oleh karena perbedaan persentase antara responden yang ketersediaan pembuangan tinjanya memenuhi syarat dan tidak memenuhi syarat tidak cukup besar, hasil analisis data yang menunjukan nilai $p$ $>0,05$ menunjukkan bahwa $\mathrm{HO}$ diterima dan $\mathrm{Ha}$ ditolak.

Berdasarkan hasil analisis bivariat dapat diketahui bahwa balita yang menderita diare lebih banyak $(38,5 \%)$ merupakan balita dengan

Retno Arienta Sari ${ }^{*}$ Mahasiswa Fakultas Kedokteran Universitas Lampung. *Email: retnoarientaar@gmail.com

Dyah Wulan Sumekar Rengganis Wardani ${ }^{2}$ Departemen llmu Kedokteran Keluarga,

Fakultas Kedokteran Universitas Lampung

Ratna Dewi Puspita Sari ${ }^{3}$ Departemen Obstetri dan Ginekologi, Fakultas Kedokteran Universitas Lampung 
Perilaku ibu rumah tangga yang mempunyai balita dan sanitasi dasar rumah dengan kejadian diare pada balita

ketersediaan pembuangan sampah yang tidak memenuhi syarat. Sedangkan balita yang tidak menderita diare paling banyak (80\%) merupakan balita dengan ketersediaan pembuangan sampah yang memenuhi syarat. Ketersediaan pembuangan sampah yang memenuhi syarat dapat menurunkan angka kejadian diare pada balita. Hasil analisis diperoleh nilai $p=0,068>$ nilai $a=0,05$. Oleh karena perbedaan persentase antara responden yang ketersediaan pembuangan sampahnya memenuhi syarat dan tidak memenuhi syarat tidak cukup besar, hasil analisis data yang menunjukan nilai $p>0,05$ menunjukkan bahwa $\mathrm{HO}$ diterima dan Ha ditolak.

Berdasarkan hasil analisis bivariat dapat diketahui bahwa balita yang menderita diare lebih banyak $(30,2 \%)$ merupakan balita dengan ketersediaan pembuangan air limbah yang tidak memenuhi syarat. Sedangkan balita yang tidak menderita diare paling banyak $(71,4 \%)$ merupakan balita yang ketersediaan pembuangan air limbahnya memenuhi syarat. Ketersediaan sarana pembuangan air limbah yang memenuhi syarat dapat menurunkan angka kejadian diare pada balita. Hasil analisis diperoleh nilai $p=1,000>$ nilai $a=0,05$. Oleh karena perbedaan persentase antara responden yang ketersediaan pembuangan air limbahnya memenuhi syarat dan tidak memenuhi syarat tidak cukup besar, hasil analisis data yang menunjukan nilai $p>0,05$ menunjukkan bahwa $\mathrm{HO}$ diterima dan $\mathrm{Ha}$ ditolak.

\section{PEMBAHASAN}

\section{Perilaku Cuci Tangan Ibu}

Hasil analisis univariat pada variabel perilaku ibu cuci tangan dengan sabun menunjukkan bahwa sebagian besar balita dengan perilaku ibu mencuci tangan dengan sabun $(60,8 \%)$ sebelum menyiapkan dan memberi makan pada balita dan setelah buang air. Hal ini sejalan dengan penelitian sebelumnya yang didapatkan bahwa perilaku ibu balita mencuci tangan lebih banyak dibandingkan dengan ibu balita yang tidak mencuci tangan (Fatmawati, Arbianingsih, \& Musdalifah, 2017; Ruhyanuddin, 2017).

Dari hasil kuesioner terkait perilaku ibu dalam kebiasaan mencuci tangan dikategorikan baik $(60,8 \%)$, hal ini dibuktikan dengan perilaku ibu selalu mencuci tangan sebelum/sesudah melakukan kegiatan, baik ketika memberikan makan anaknya, sebelum sesudah BAB/BAK, setelah membuang sampah ataupun ketika kondisi tangan ibu kotor. Namun ada beberapa ibu yang tidak memiliki kebiasaan mencuci tangan dengan sabun $(39,2 \%)$ karena alasan terlupa dan repot jika harus memakai sabun dahulu.

\section{Perilaku Memasak Air Minum}

Pada penelitian ini diketahui bahwa sebagian besar perilaku ibu balita memasak air minum hingga matang $(75,5 \%)$. Hal ini sejalan dengan penelitian sebelumnya di dapatkan bahwa sebagian besar memiliki perilaku memasak air minum hingga matang (mendidih) sebelum dikonsumsi (Laksmi, Windiani, \& Hartawan, 2013; Cita, 2014). Namun bila di lihat dari hasil jawaban responden dari penelitian ini, angka nya lebih tinggi dibandingkan penelitian sebelumnya.

Berdasarkan hasil penelitian ini, didapatkan bahwa perilaku ibu balita yang tidak memasak air minum hingga matang tetapi mereka menggunakan sterilight air minum isi ulang. Pada penelitian sebelumnya sterilight air minum isi ulang Menurut masih dikatakan tidak cukup bersih untuk dikonsumsi karena kadang prosesnya masih belum cukup steril sehingga masih mengandung bakteri seperti Salmonella sp., dan bakteri patogen lainnya yang dapat menyebabkan berbagai penyakit (Aini, Raharjo, \& Budiyono, 2016).

\section{Ketersediaan Sarana Air Bersih}

Berdasarkan ketersediaan air bersih diketahui bahwa sebagian besar ibu $(59,8 \%)$ memiliki ketersediaan air bersih yang memenuhi syarat. Hal ini sesuai dengan penelitian sebelumnya di Tambak Sari, Kota Surabaya, tetapi berbeda dengan hasil temuan penelitian di wilayah kerja Puskesmas Pilolodaa Kecamatan Kota Barat Kota Gorontalo bahwa responden yang menggunakan sarana penyediaan air bersih yang tidak memenuhi syarat lebih banyak (Prawati (2019; Bumolo, 2014). Pada saat observasi, didapatkan banyak responden yang sudah memiliki ketersediaan sarana air bersih yang memenuhi syarat yaitu memiliki jumlah ketersediaan air yang cukup, berkualitas, dan jarak sumber air dari sumber pencemaran minimal 10 meter. Namun masih ada responden yang sarana ketersediaan air bersihnya tidak memenuhi syarat seperti jumlah ketersediaan airnya tidak cukup $(12,7 \%)$, airnya masih berwarna, bau, dan berasa $(23,5 \%)$, dan jarak

Retno Arienta Sari ${ }^{*}$ Mahasiswa Fakultas Kedokteran Universitas Lampung. *Email: retnoarientaar@gmail.com

Dyah Wulan Sumekar Rengganis Wardani ${ }^{2}$ Departemen llmu Kedokteran Keluarga,

Fakultas Kedokteran Universitas Lampung

Ratna Dewi Puspita Sari ${ }^{3}$ Departemen Obstetri dan Ginekologi, Fakultas Kedokteran Universitas Lampung 
Perilaku ibu rumah tangga yang mempunyai balita dan sanitasi dasar rumah dengan kejadian diare pada balita

sumber air dari sumber pencemaran kurang dari 10 meter $(30,4 \%)$.

Berdasarkan hasil observasi, sebagian responden masih ada yang menggunakan air sumur untuk keperluan sehari-hari, ada yang menggunakan air tanah dengan pompa, dan ada juga yang sumber airnya berasal dari PAM. Pada saat penelitian, berdasarkan observasi, air yang berasal dari pompa sendiri masih terasa asin dan tidak jernih. Selain itu, karena pada saat penelitian sedang musim kemarau sehingga mereka menggunakan air sumur yang sudah lama tidak digunakan namun airnya masih dapat dipakai walaupun tidak layak untuk digunakan untuk keperluan sehari-hari. Berdasarkan hasil observasi mengenai sarana air bersih, ternyata banyak responden yang tidak memenuhi syarat kesehatan yaitu jarak $S A B$ yang kurang dari 11 meter dan air masih berasa dan berwarna keruh.

Jenis sumber air untuk seluruh kebutuhan rumah tangga di Indonesia pada umumnya adalah sumur gali terlindung $(29,2 \%)$, sumur pompa $(24,1 \%)$, dan air ledeng/PDAM (19,7\%). Di perkotaan, lebih banyak rumah tangga yang menggunakan air dari sumur bor/pompa $(32,9 \%)$ dan air ledeng/PDAM (28,6\%), sedangkan di perdesaan lebih banyak yang menggunakan sumur gali terlindung (32,7\%) (Kementerian Kesehatan Republik Indonesia, 2013). Sumber Air untuk keperluan minum maupun memasak, kualitas air yang digunakan harus tersedia dalam jumlah yang cukup dan layak. Air minum adalah air yang kualitasnya memenuhi syarat kesehatan dan dapat langsung diminum. Air tersebut harus memenuhi syarat kesehatan baik dari segi fisik, kimiawi, dan bekteriologi agar tidak menimbulkan penyakit bagi pengonsumsinya termasuk diare (Notoatmodjo, 2007).

\section{Ketersediaan Sarana Jamban}

Hasil karakteristik responden berdasarkan pembuangan tinja diketahui bahwa sebagian besar balita dengan ketersediaan sarana pembuangan tinja yang tidak memenuhi syarat lebih banyak $(54,9 \%)$ daripada yang memenuhi syarat. Hasil temuan ini sama dengan beberapa penelitian sebelumnya, namun angkanya lebih kecil dibandingkan penelitian di kecamatan Kedaton Bandar Lampung (Umar, 2016; Cita, 2014; Rahman, Widoyo, \& Siswanto, 2016).
Pada penelitian ini, ketersediaan sarana pembuangan limbah yang memenuhi syarat adalah yang memenuhi kriteria berjarak minimal 10 meter dari sumber air, tidak bocor dan tidak mencemari lingkungan, dan tertutup. Pada penelitian ini didapatkan sebagian besar responden rata-rata belum mempunyai saluran pembuangan air limbah yang baik. Banyak di antaranya saluran pembuangan air limbahnya langsung mengarah ke laut yang berada di dekat lingkungan rumahnya sehingga menyebabkan pencemaran lingkungan. Hal yang lain juga terdapat beberapa rumah yang memiliki saluran pembuangan air limbah dekat dengan sumber air seperti dekat sumur pompa. Selain itu tempat pembuangan air limbah yang dimiliki responden juga ada yang suka tersumbat dan menggenang. Namun masih ada beberapa responden yang sudah memiliki pembuangan limbah yang memenuhi syarat.

Proporsi rumah tangga berdasarkan penampungan air limbah dari kamar mandi, tempat cuci, maupun dapur. Pada umumnya limbah rumah tangga di Indonesia membuang limbahnya langsung ke got $(46,7 \%)$ dan tanpa penampungan $(17,2 \%)$. Hanya 15,5 persen yang menggunakan penampungan tertutup di pekarangan dengan dilengkapi SPAL, 13,2 persen menggunakan penampungan terbuka di pekarangan, dan 7,4 persen penampungannya di luar pekarangan (Kementerian Kesehatan Republik Indonesia, 2013).

\section{Kejadian Diare pada Balita}

Pada variabel kejadian diare pada balita menunjukkan bahwa sebagian besar balita $(70,6 \%)$ tidak mengalami kejadian diare. Hal ini sama dengan temuan penelitian sebelumnya di Makassar dan Kabupaten Wojo yang menyatakan bahwa sebagian besar balita tidak mengalami kejadian diare. Namun presentasenya dari angka kejadian diare yang lebih rendah dibandingkan dengan penelitian di Kabupaten Wojo (Fatmawati, Arbianingsih, \& Musdalifah, 2017; Dahyuniar, 2018).

Namun temuan ini berbeda dengan penelitian di wilayah kerja Puskesmas Sukawati yang menunjukkan bahwa balita yang mengalami kejadian diare lebih banyak $(70 \%)$ dibandingkan yang tidak mengalami kejadian diare (Laksmi, Windiani, \& Hartawan, 2013).

Retno Arienta Sari ${ }^{*}$ Mahasiswa Fakultas Kedokteran Universitas Lampung. *Email: retnoarientaar@gmail.com

Dyah Wulan Sumekar Rengganis Wardani ${ }^{2}$ Departemen llmu Kedokteran Keluarga,

Fakultas Kedokteran Universitas Lampung

Ratna Dewi Puspita Sari ${ }^{3}$ Departemen Obstetri dan Ginekologi, Fakultas Kedokteran Universitas Lampung 
Perilaku ibu rumah tangga yang mempunyai balita dan sanitasi dasar rumah dengan kejadian diare pada balita

\section{Perilaku Cuci Tangan Ibu}

Pada penelitian ini dikemukakan bahwa ada hubungan yang signifikan antara perilaku cuci tangan ibu dengan kejadian diare pada balita (nilai $p=0,035)$. Hal ini sama dengan penelitian sebelumnya di Desa Tegowanu Wetan Grobogan dan di Kersana Kabupaten Brebes (Muliawan, 2009; Kusumawati, Nugroho, \& Hartono, 2012). Faktor kejadian diare tidak hanya disebabkan oleh faktor sanitasi makanan saja, tetapi juga dapat disebabkan oleh perilaku kebersihan perorangan. Salah satunya adalah mencuci tangan dan faktor budaya juga mempengaruhi kejadian diare pada balita. Mencuci tangan dengan sabun dan air bersih yang mengalir terutama setelah buang air besar, setelah membuang tinja anak, sebelum menyiapkan makanan, dan sebelum menyuapi anak dapat menurunkan angka kejadian diare sebesar $47 \%$. Perilaku ibu yang tidak mencuci tangan dengan sabun sebelum menyiapkan dan menyuapi anak adalah tindakan yang sangat berisiko menyebabkan diare karena makanan tersebut telah tercemar mikroorganisme penyebab penyakit (Sirait, 2013; Rosidi, Handarsari, \& Mahmudah, 2010).

Salah satu pencegahan diare yang benar dan efektif adalah dengan mencuci tangan menggunakan air dan sabun sebelum makan dan sesudah buang air besar. Seseorang yang mempunyai perilaku hygiene yang baik akan menurunkan risiko terjangkit penyakit diare. Begitu juga sebaliknya, jika perilaku hygiene jelek maka risiko terjangkit diare akan lebih besar karena makanan tersebut akan terkontaminasi mikroorganisme penyebab penyakit dan dapat menyebabkan penyakit, seperti diare, kolera, typhoid, maupun hepatitis $A$. Ibu berperan penting dalam menyiapkan makanan untuk anak (Kementerian Kesehatan Republik Indonesia, 2011; Susanti, 2014).

\section{Perilaku Memasak Air Minum}

Penelitian ini mengemukakan bahwa ada hubungan yang bermakna antara memasak air minum dengan kejadian diare pada balita (nilai $p=$ 0,036). Penelitian ini sama dengan penelitian sebelumnya bahwa prevalensi kasus diare pada penggunaan air minum yang direbus lebih sedikit dibandingkan yang tidak direbus (Aini, Raharjo, \& Budiyono, 2016; Amaliah, 2010). Sebagian besar responden pada penelitian ini menggunakan air sterilight air minum isi ulang. Sterilight air minum isi ulang telah melewati beberapa pengolahan air yang dapat menjaga kualitas air dan mencegah adanya mikroorganisme. Proses pengolahan air yang dimaksud adalah proses penyaringan, pengendapan, disinfeksi dan sistem ozonisasi atau reverse oxidation.

Pada beberapa kasus, sterilight air minum isi ulang dapat terjadi pencemaran saat melakukan pemindahan tempat penyimpanan air ke dalam teko. Sebelum dimasukkan ke teko atau penyimpanan lain, air dalam keadaan terbuka. Hal ini akan memperbesar risiko terjadinya pencemaran kembali pada air minum. Sedangkan, balita yang mengkonsumsi air yang belum dimasak seperti sterilight air minum isi ulang tetap dapat mengalami diare karena tempat penyimpanan air atau dispenser yang tidak bersih. Dispenser yang berbentuk besar sulit untuk dilakukan pencucian, sehingga air sisa galon yang tergenang pada dispenser dapat menjadi tempat pertumbuhan bakteri serta udara sekitar yang mengandung mikroorganisme dapat berkontak dengan air tersebut sehingga memperbesar terjadinya pencemaran kembali. Udara mengandung bakteri gram negatif dimana bakteri tersebut lebih mudah beradaptasi dengan lingkungan sekitar sehingga untuk terjadinya pertumbuhan dan perkembangbiakan bakteri lebih cepat daripada bakteri gram positif (Aini, Raharjo, \& Budiyono, 2016).

\section{Ketersediaan Sarana Air Bersih}

Hasil penelitian ini diketahui bahwa dari 41 responden memiliki ketersediaan sarana air bersih yang tidak memenuhi syarat terdapat 17 responden $(41,5 \%)$ menderita diare dan yang tidak diare sebesar 24 responden (58,5\%). Sedangkan dari 61 responden memiliki ketersediaan air bersih yang memenuhi syarat terdapat sebanyak 13 responden $(21,3 \%)$ menderita diare dan 48 responden $(78,7 \%)$ tidak menderita diare. Analisis chi square memperoleh hasil nilai $p=0,049<$ nilai $\mathrm{a}=0,05$ artinya $\mathrm{HO}$ ditotak dan Ha diterima. Maka, dapat disimpulkan bahwa ada hubungan yang bermakna antara ketersediaan air bersih dengan kejadian diare pada balita. Penelitian ini sesuai sama dengan riset sebelumnya yang mengatakan bahwa terdapat hubungan ketersediaan sumber air dengan kejadian diare. Hasil penelitian ini sesuai dengan penelitian yang telah dilakukan

Retno Arienta Sari ${ }^{*}$ Mahasiswa Fakultas Kedokteran Universitas Lampung. *Email: retnoarientaar@gmail.com

Dyah Wulan Sumekar Rengganis Wardani² Departemen llmu Kedokteran Keluarga,

Fakultas Kedokteran Universitas Lampung

Ratna Dewi Puspita Sari ${ }^{3}$ Departemen Obstetri dan Ginekologi, Fakultas Kedokteran Universitas Lampung 
Perilaku ibu rumah tangga yang mempunyai balita dan sanitasi dasar rumah dengan kejadian diare pada balita

sebelumnya di Kabupaten Sambas tahun 2006 (Zulkibli, 2007; Wandasari, 2013).

Air yang digunakan sebagai air minum harus aman dan memenuhi berbagai syarat kesehatan. Air minum yang baik harus memenuhi persyaratan fisik, syarat bakteriologis dan syarat kimia. Persyaratan fisik yang digunakan sebagai standar untuk menentukan air minum yang sehat adalah tidak berwarna, tidak berasa, tidak berbau dan suhunya berada di bawah suhu lingkungan sekitarnya. Secara bakteriologis, air minum yang sehat harus bebas dari segala bakteri, terutama bakteri-bakteri yang memiliki sifat pathogen dan berbahaya bagi peminumnya. Air minum yang sehat harus mengandung zat-zat tertentu dalam jumlah tertentu pula yang sesuai. Air yang dapat dikatakan bersih memiliki kadar keasaman atau $\mathrm{PH}$ 7 dan jumlah oksigen terlarut jenuh $9 \mathrm{mg} / \mathrm{l}$ (Kementerian Pendidikan dan Kebudayaan Republik Indonesia, 2018).

\section{Ketersediaan Sarana Jamban}

Berdasarkan hasil analisis bivariat dapat diketahui dari 56 responden $(54,9 \%)$ memiliki pembuangan tinja yang tidak memenuhi syarat dan 46 responden $(45,1 \%)$ memiliki pembuangan tinja yang memenuhi syarat. Hasil ini sama dengan penelitian sebelumnya bahwa masih banyak responden memiliki jamban yang tidak sesuai dengan standar seperti di wilayah kerja Puskesmas Pilolodaa Kecamatan Kota Barat Kota Gorontalo tahun 2012 (Bumulo, 2014; Umar, 2016).

Pada uji analisis penelitian ini diperoleh nilai $p$ $=0,078$ yang dapat disimpulkan bahwa tidak ada hubungan yang bermakna antara pembuangan tinja dengan kejadian diare pada balita. Bila dilihat dari beberapa riset sebelumnya, hasil ini menunjukan perbedaan hasil beberapa penelitian sebelumnya yang menunjukan adanya hubungan pembuangan tinja dengan kejadian diare (Umar, 2016; Umiati, 2010; Cita, 2014). Pada penelitian ini menggambarkan bahwa sebagian besar responden memiliki kebiasaan membuang tinja pada balita yang tidak sesuai dengan penangan tinja yang benar. Hal ini memang sesuai dengan keadaan di sebagian besar masyarakat di Indonesia. Data Riskesdas tahun 2018 menunjukan data nasional proporsi cara penangan tinja balita di rumah tangga hanya terdapat $37,8 \%$ yang menggunakan jamban sebagai pembuangan tinja. Pembuangan tinja balita di sembarang tempat masih cuku tinggi $(33,5 \%)$. Pada data di Provinsi Lampung pun juga menunjukan pembuangan tinja balita menggunakan jamban hanya sekitar 39\% dan diikuti sebanyak 22,6\% yang dibuang secara sembarangan (Kementerian Kesehatan Republik Indonesia, 2019).

Hasil pengamatan langsung terhadap responden menunjukan bahwa masyarakat di Kelurahan Kangkung memiliki perilaku yang membuang tinja dengan tidak benar. Sebagian besar membuang tinja ke tempat pembuangan sampah yang ada di sekitar rumah. Hal ini dikarenakan tinja balita yang dibuang bersamaan dengan popok yang dipakai. Namun ada beberapa pengamatan yang menunjukan penggunaan popok kain yang dapat dicuci berkali - kali apabila terkena kotoran. Masyarakat beranggapan bahwa tinja balita tidak berbaya dan mengandung sedikit kuman. Balita masih memiliki pola makan yang tidak bervariasi sehingga mereka beranggapan kontaminasi kuman atau mikroorganisme penyebab diare jumlahnya minimal. Sedangkan menurut Departemen Kesehatan, tinja balita juga dapat menularkan penyakit pada balita itu sendiri dan pada orang tuanya. Tinja yang dibuang di tempat terbuka dapat dihinggapi lalat. Lalat untuk bertelur dan berkembang biak di tempat tersebut yang kemudian dapat hinggap ke beberapa tempat di sekitar rumah yang dapat berperan dalam penularan penyakit melalui tinja (fecal borne disease) (Kementerian Kesehatan Republik Indonesia, 2000).

\section{Ketersediaan Sarana Pembuangan Sampah}

Pada penelitian ini diketahui dari 50 responden memiliki ketersediaan pembuangan sampah yang tidak memenuhi syarat terdapat 20 responden $(40 \%)$ menderita diare dan yang tidak diare sebesar 30 responden (60\%). Sedangkan dari 52 responden memiliki pembuangan tinja yang memenuhi syarat terdapat sebanyak 10 responden $(19,2 \%)$ menderita diare dan 42 responden $(80,8 \%)$ tidak menderita diare. Pada penelitian ini diketahui dari 52 responden memiliki ketersediaan pembuangan sampah yang tidak memenuhi syarat terdapat 20 responden $(38,5 \%)$ menderita diare dan yang tidak diare sebesar 32 responden $(61,5 \%)$. Sedangkan dari 50 responden memiliki pembuangan tinja yang memenuhi syarat terdapat sebanyak 10 responden (20\%) menderita diare

Retno Arienta Sari ${ }^{*}$ Mahasiswa Fakultas Kedokteran Universitas Lampung. *Email: retnoarientaar@gmail.com

Dyah Wulan Sumekar Rengganis Wardani ${ }^{2}$ Departemen llmu Kedokteran Keluarga,

Fakultas Kedokteran Universitas Lampung

Ratna Dewi Puspita Sari ${ }^{3}$ Departemen Obstetri dan Ginekologi, Fakultas Kedokteran Universitas Lampung 
Perilaku ibu rumah tangga yang mempunyai balita dan sanitasi dasar rumah dengan kejadian diare pada balita

dan 40 responden $(80 \%)$ tidak menderita diare. Hasil analisis tidak terdapat hubungan signifikan antara ketersediaan pembuangan sampah dengan kejadian diare (nilai $p=0,068$ ).

Hasil penelitian ini sama dengan penelitian sebelumnya yang menyatakan tidak ada hubungan sarana tempat pembuangan sampah dengan kejadian diare di Desa Tanjung Pinang Kecamatan Kusambi Kabupaten Muna Barat (Armin, \& Munandar, 2018; Dahyuniar, 2018). Namun, ada juga yang beda dengan penelitian sebelumnya dimana terdapat hubungan pembuangan sampah dengan diare (Soamole, 2018; Umar, 2016).

Sampah adalah sisa kegiatan sehari-hari manusia dan atau proses alam yang berbentuk padar. Sampah merupakan sumber penyakit dan tempat berkembangnya vektor penyakit seperti lalat, kecoa, dan sebagainya (Kementerian Pendidikan dan Kebudayaan Republik Indonesia, 2018). Pada penelitian ini, semua responden ratarata sudah mempunyai tempat pembuangan sampah yang akan diambil pihak kebersihan secara rutin namun tempat pembuangan sampah sementara masih ada yang tidak memenuhi syarat kesehatan seperti di taruh saja diplastik tanpa ada tempat penutupnya dan ada juga yang di biarkan di halaman rumah. Dalam pengelolaan sampah hanya 24,9 persen rumah tangga di Indonesia yang pengelolaan sampahnya diangkut oleh petugas. Sebagian besar rumah tangga mengelola sampah dengan cara dibakar $(50,1 \%)$, ditimbun dalam tanah $(3,9 \%)$, dibuat kompos $(0,9 \%)$, dibuang ke kali/parit/laut $(10,4 \%)$, dan dibuang sembarangan (9,7\%). Lima provinsi dengan proporsi rumah tangga mengelola sampah dengan cara diangkut petugas tertinggi adalah DKI Jakarta (87\%), Kepulauan Riau (55,8\%), Kalimantan Timur $(49,9 \%)$, Bali $(38,2 \%)$, dan Banten $(34,4 \%)$. Lima provinsi dengan proporsi tertinggi untuk rumah tangga yang mengelola sampahnya dengan dibakar adalah Gorontalo (79,5\%), Aceh $(70,6 \%)$, Lampung $(69,9 \%)$, Riau $(66,4 \%)$, Kalimantan Barat $(64,3 \%)$. Lima provinsi terendah adalah DKI Jakarta (5,3\%), Maluku Utara (25,9\%), Maluku (28,9\%), Kepulauan Riau (31\%), Kalimantan Timur $(32,1 \%) \quad$ (Kementerian Kesehatan Republik Indonesia, 2013).

Membuang sampah sembarangan merupakan salah satu pelanggaran etika yang sering dijumpai, ada banyak dampak negatif yang ditimbulkan dari membuang sampah sembarangan yaitu seperti banjir, wabah penyakit seperti penyakit diare (Wibisono, 2014). Pada penelitian ini, terdapat beberapa responden yang mempunyai kebiasaan membuang sampah ke pantai dan disekitar tanah lapang pekarangan rumah sangat mengganggu penglihatan dan mencemari daerah sekitar. Dengan adanya sampah yang tidak tertutup dapat mengundang lalat dan insekta lain sehingga kejadian diare lebih besar dibandingkan dengan sampah yang tertutup (Fikri, 2019). Pengelolaan sampah yang tidak memenuhi syarat menyebabkan lebih banyak diare karena sampah yang tidak diolah atau dibuang sembarangan dapat menjadi tempat yang baik bagi perkembangbiakan serangga dan mikroorganisme, serangga sebagai pembawa mikroorganisme patogen dapat menyebarkan berbagai macam penyakit (Saleh, 2014).

\section{Ketersediaan Sarana Pembuangan Limbah}

Pada penelitian ini diketahui tidak terdapat hubungan yang bermakna antara sarana pembuangan air limbah dengan kejadian diare pada balita (nilai $p=1,000$ ). Hasil penelitian ini sama dengan hasil beberapa penelitian sebelumnya seperti di Kelurahan Sukaraja Kecamatan Medan Maimun Kota Medan (Dahyuniar, 2018; Angeline, Marsaulina, \& Naria, 2013). Hasil penemuan penelitian ini ada yang tidak sama dengan sebelumnya seperti di Kecamatan Jatipuro Kabupaten Karanganyar yang menunjukkan bahwa ada hubungan bermakna antara pembuangan air limbah dengan kejadian diare pada balita. Selain itu, hasil penelitiannya menunjukkan bahwa odds ratio yang didapatkan yaitu 2,5 atau memiliki risiko 2 kali untuk terjadinya diare pada balita (Bintoro, \& Rochman, 2010).

Pembuangan air limbah yang tidak baik akan menyebabkan berbagai gangguan kesehatan masyarakat lingkungan hidup antara lain menjadi transmisi atau media penyebaran berbagai penyakit, menjadi media berkembangbiaknya mikroorganisme patogen, menjadi tempat berkembangbiaknya nyamuk atau tempat hidup larva nyamuk, menimbulkan bau yang tidak enak serta pandangan yang tidak sedap, dan menjadi sumber pencemaran air permukaan, tanah, dan lingkungan hidup lainnya (Notoatmodjo, 2007). Sarana pembuangan air limbah rumah tangga pada penelitian ini mayoritas responden langsung mengalirkan langsung ke got/sungai sebesar

Retno Arienta Sari ${ }^{*}$ Mahasiswa Fakultas Kedokteran Universitas Lampung. *Email: retnoarientaar@gmail.com

Dyah Wulan Sumekar Rengganis Wardani ${ }^{2}$ Departemen llmu Kedokteran Keluarga,

Fakultas Kedokteran Universitas Lampung

Ratna Dewi Puspita Sari ${ }^{3}$ Departemen Obstetri dan Ginekologi, Fakultas Kedokteran Universitas Lampung 
Perilaku ibu rumah tangga yang mempunyai balita dan sanitasi dasar rumah dengan kejadian diare pada balita

$54,5 \%$, masyarakat lebih memilih langsung membuangnya penampungan terbuka dipekarangan rumah sebesar $42,9 \%$. Responden yang memiliki sarana pembuangan air limbah hanya sebesar $2,6 \%$. Tanpa adanya sarana pembuangan air limbah domestik, kesehatan masyarakat menurun dan mempengaruhi produktivitas masyarakat setempat. Ketersediaan sistem pengolahan air limbah domestik secara terpusat diharapkan dapat mengurangi tingkat pencemaran air sungai dan meningkatkan kualitas lingkungan yang berimplikasi kepada peningkatan derajat kesehatan masyarakat (Sapei, Purwanto, \& Kurniawan, 2011)

\section{SIMPULAN}

Dari penelitian ini didapatkan beberapa faktor yang berhubungan erat antara kejadian diare pada balita, dengan perilaku ibunya seperti kebiasaan cuci tangan, penyediaan air minum, dan ketersediaan air bersih yang memenuhi syarat. Sedangkan faktor lainnya seperti pembuangan tinja, pembuangan sampah, dan pembuangan air limbah, tidak didapatkan hubungan dengan kejadian diare pada balita.

\section{SARAN}

Diare merupakan salah-satu penyebab kematian balita tertinggi di seluruh dunia dan termasuk di Indonesia. Perlunya kegiatan yang melibatkan masyarakat dari tingkat keluarga, rukun tetangga sampai pemerintahan desa yang didukung oleh dinas kesehatan, puskesmas, sekolah dengan tujuan merubah perilaku PHBS masyarakat. Kegiatan tersebut harus selalu diberikan berupa penyuluhan, pengawasan, motivasi, reward dan tindakan pencegahan didukung dengan peningkatan sanitasi kesehatan berupa pembanguan fasilitas pendukung misalnya pipanisasi air bersih, penyediaan pembuangan sampah akhir dan menggali potensi kearifan lokal pendukung kesehatan. Untuk peneliti selanjutnya supaya dapat mendalami lagi penelitiannya baik secara kualitatif maupun kuantitatif tentang faktorfaktor yang berhubungan erat dengan kejadian diare pada balita, dan disamping itu dan mendapatkan upaya penanganan pertama bila menghadapi diare pada balita.

\section{DAFTAR PUSTAKA}

Aini, N., Raharjo, M., \& Budiyono, B. (2016). Hubungan kualitas air minum dengan kejadian diare pada balita di wilayah kerja puskesmas Banyuasin Kecamatan Loano Kabupaten Purworejo (The Relationship Between The Quality Of Drinking Water and The Occurrence Of Diarrhea In Children Under Five Years In. Jurnal Kesehatan Masyarakat (eJournal), 4(1), 309-406.

Amaliah, S. (2010). Hubungan Sanitasi Lingkungan dan Faktor Budaya dengan Kejadian Diare pada Anak Balita di Desa Toriyo Kecamatan Bendosari Kabupaten Sukoharjo. In prosiding seminar nasional \& internasional.

Angeline, Y. L., Marsaulina, I., \& Naria, E. (2013). Hubungan kondisi sanitasi dasar dengan keluhan kesehatan diare serta kualitas air pada pengguna air sungai Deli di kelurahan Sukaraja Kecamatan Medan Maimun Tahun 2012. Lingkungan dan Kesehatan Kerja, 2(3).

Armin, A., \& Munandar, S. (2018). Hubungan sanitasi lingkungan dengan kejadian penyakit diare di desa tanjung pinang kecamatan Kusambi Kabupaten Muna Barat Tahun 2017. Jurnal IImiah Mahasiswa Kesehatan Masyarakat, 2(7).

Bintoro, T., \& Rochman, B. (2010). Hubungan antara sanitasi lingkungan dengan kejadian diare pada balita di kecamatan Jatipuro Kabupaten Karanganyar (Doctoral dissertation, Universitas Muhammadiyah Surakarta).

Bumulo, S. B. (2014). Hubungan sarana penyediaan air bersih dan jenis jamban keluarga dengan kejadian diare pada anak balita di wilayah kerja Puskesmas Pilolodaa Kecamatan Kota Barat Kota Gorontalo Tahun 2012 (Doctoral dissertation, Universitas Negeri Gorontalo).

\footnotetext{
Retno Arienta Sari ${ }^{*}$ Mahasiswa Fakultas Kedokteran Universitas Lampung. *Email: retnoarientaar@gmail.com Dyah Wulan Sumekar Rengganis Wardani ${ }^{2}$ Departemen llmu Kedokteran Keluarga,

Ratna Dewi Puspita Sari ${ }^{3}$ Departemen Obstetri dan Ginekologi, Fakultas Kedokteran Universitas Lampung
} 
Perilaku ibu rumah tangga yang mempunyai balita dan sanitasi dasar rumah dengan kejadian diare pada balita

Cita, R. S. (2014). Hubungan sarana sanitasi air bersih dan perilaku ibu terhadap kejadian diare pada balita umur 10-59 bulan di wilayah puskesmas Keranggan Kecamatan Setu Kota Tangerang Selatan Tahun 2013.

Dahyuniar, D. (2018). Hubungan Antara Sanitasi dengan Kejadian Diare di Wilayah Rawan banjir Kecamatan Tanasitolo Kabupaten Wajo. [skripsi]. Makassar: Universitas Hasanuddin. Diakses dari: http://digilib.unhas.ac.id/uploaded_files/tempora ry/DigitalCollection/ODgxNzlzNWE1NDQyY2lw ZGUxNmQ4YjFkZmE2MzcwZmE4NTI4MTU1N $\mathrm{W}==. \mathrm{pdf}$

Dinas Kesehatan Kota Bandar Lampung. 2019. Profil Kesehatan Kota Bandar Lampung Tahun 2018. Bandar Lampung: Dinas Kesehatan Kota Bandar Lampung. Diakses dari: https://www.depkes.go.id/resources/download/i nfo-

terkini/materi_rakorpop_2018/Hasil\%20Riskesd as\%202018.pdf

Dinas Kesehatan Provinsi Lampung. (2018).Profil Kesehatan Provinsi Lampung 2018. Diakses dari: https://e-renggar.kemkes.go.id/file2018/eperformance/1-129006-2tahunan-984.docx

Faisal, N., Sriwahyuni, E., \& Afandhi, A. (2016). The Influence of The Environment And Mother's Behaviour Towards Toddlers' Diarrhea in Banjarbaru, South Kalimantan. Indonesian Journal of Environment and Sustainable Development, 7(2).

Fatmawati, F., Arbianingsih, A., \& Musdalifah, M. (2017). Faktor yang mempengaruhi kejadian diare anak usia 3-6 tahun di TK Raudhatul Athfal Alauddin Makassar. Journal of Islamic Nursing, 1(1), 21-32.
Fikri, V. A. R. (2019). Faktor-faktor sanitasi yang berpengaruh terhadap timbulnya penyakit diare pada balita di puskesmas Depok Jaya Periode Februari-Maret 2012.

International Vaccine Access Center.( 2018). Pneumonia \& Diarrhea Progress Reports 2018. Diakses dari: https://stoppneumonia.org/wpcontent/uploads/2018/10/JHSPH_PDPR_2018_ Final_small.pdf

Kementerian Kesehatan Republik Indonesia. (2000). Buku Pedoman Pelaksanaan P2 Diare. Jakarta: Kementerian Kesehatan Republik Indonesia. Diakses dari: http://perpustakaan.kemkes.go.id/inlislite3/opac /detail-opac?id=2499

Kementerian Kesehatan Republik Indonesia. (2011). Panduan Pembinaan dan Penilaian Perilaku Hidup Bersih dan Sehat di Rumah Tangga. Jakarta: Kementerian Kesehatan RI. Diakses dari: http://promkes.kemkes.go.id/pedoman-phbs

Kementerian Kesehatan Republik Indonesia. (2013). Riset Kesehatan Dasar Kementerian Kesehatan Republik Indonesia 2013. Diakses dari:

http://www.depkes.go.id/resources/download/g eneral/Hasil\%20Riskesdas\%202013.pdf

Kementerian Kesehatan Republik Indonesia. (2019). Laporan Nasional Riskesdas 2018. Jakarta: Lembaga Penerbit Badan Penelitian dan Pengembangan Kesehatan Kementerian Kesehatan RI.

Kementerian Kesehatan Republik Indonesia.(2018). Potret sehat Indonesia dari riskesdas 2018 - Kementerian Kesehatan Republik Indonesia. Diakses dari: https://www.depkes.go.id/article/view/18110200 003/potret-sehat-indonesia-dari-riskesdas2018.html

Retno Arienta Sari" Mahasiswa Fakultas Kedokteran Universitas Lampung. *Email: retnoarientaar@gmail.com Dyah Wulan Sumekar Rengganis Wardani ${ }^{2}$ Departemen Ilmu Kedokteran Keluarga, 
Perilaku ibu rumah tangga yang mempunyai balita dan sanitasi dasar rumah dengan kejadian diare pada balita

Kementerian Pendidikan dan Kebudayaan

Republik Indonesia (2018). Pedoman Pengembangan Sanitasi Sekolah Dasar. Jakarta: Kementerian Pendidikan dan Kebudayaan Direktorat Jenderal Pendidikan Dasar dan Menengah. Diakses dari: http://repositori.kemdikbud.go.id/6029/1/PetaJalan-Sanitasi-Sekolah.pdf

Kusumawati, O., Nugroho, H. A., \& Hartono, R. (2012). Hubungan Perilaku Hidup Bersih dan Sehat dengan Kejadian Diare pada Balita Usia 1-3 Tahun Studi Kasus di Desa Tegowanu Wetan Kecamatan Tegowanu Grobogan. Karya IImiah.

Laksmi, N. P. A., Windiani, I. T., \& Hartawan, I. N. B. (2013). Hubungan perilaku ibu terhadap kejadian diare pada balita di wilayah kerja puskesmas Sukawati I Periode Bulan November Tahun 2013. E-Jurnal Medika Udayana.

Mauliku, H. E., \& Wulansari, E. (2008). Hubungan antara faktor perilaku ibu dengan kejadian diare pada balita di puskesmas Batujajar Kabupaten Bandung Barat. Jurnal Kesehatan Kartika Stikes A. Yani, 40-51

Muliawan, T. A. (2009). Hubungan antara perilaku hidup bersih dan sehat pada tatanan rumah tangga dengan kejadian diare pada anak umur 6-12 tahun di wilayah kerja puskesmas Kersana Kabupaten Brebes tahun 2008 (Doctoral dissertation, Universitas Negeri Semarang).

Notoatmodjo, S. (2007). Promosi kesehatan dan ilmu perilaku.

Prawati, D. D. (2019). Faktor yang mempengaruhi kejadian diare di Tambak Sari Kota Surabaya. Jurnal Promkes: The Indonesian Journal of Health Promotion and Health Education, 7(1), 34-45.
Rahman, H. F., Widoyo, S., \& Siswanto, H. (2016). Biantoro. Faktor-faktor yang berhubungan dengan kejadian diare di desa Solor Kecamatan Cermee Bondowoso.

Rosidi, A., Handarsari, E., \& Mahmudah, M. (2010). Hubungan kebiasaan cuci tangan dan sanitasi makanan dengan kejadian diare pada anak SD Negeri Podo 2 Kecamatan Kedungwuni Kabupaten Pekalongan. Jurnal Kesehatan Masyarakat Indonesia, 6(1).

Ruhyanuddin, F. (2017). The impact of hand washing on the incident of diarrhea among school-aged children at the District of Malang. Jurnal Keperawatan, 8(1).

Saleh, M. (2014). Hubungan kondisi sanitasi lingkungan dengan kejadian diare pada anak balita di wilayah kerja puskesmas Baranti Kabupaten Sidrap Tahun 2013. Jurnal Kesehatan, 7(1).

Sapei, A., Purwanto, M. Y. J., \& Kurniawan, A. (2011). Desain instalasi pengolah limbah WC komunal masyarakat pinggir sungai desa Lingkar Kampus. Jurnal IImu Pertanian Indonesia, 16(2), 91-99.

Sirait, E. D. (2013). Hubungan pengetahuan dan perilaku hidup bersih dan sehat ibu dengan kejadian diare pada anak usia 1-4 tahun di Puskesmas Siantan Hilir tahun 2013. Jurnal Mahasiswa PSPD FK Universitas Tanjungpura, 3(1).

Soamole, S. (2018). Analisis hubungan antara faktor lingkungan dengan kejadian diare di puskesmas Siko Kota Ternate Tahun 2017. Hibualamo: Seri IImu-IImu Alam dan Kesehatan, 2(1), 26-35.

Retno Arienta Sari ${ }^{*}$ Mahasiswa Fakultas Kedokteran Universitas Lampung. *Email: retnoarientaar@gmail.com Dyah Wulan Sumekar Rengganis Wardani ${ }^{2}$ Departemen llmu Kedokteran Keluarga,

Ratna Dewi Puspita Sari ${ }^{3}$ Departemen Obstetri dan Ginekologi, Fakultas Kedokteran Universitas Lampung 
Perilaku ibu rumah tangga yang mempunyai balita dan sanitasi dasar rumah dengan kejadian diare pada balita

Susanti, A. (2014). Hubungan Sanitasi Lingkungan Dengan Kejadian Diare Pada Balita Di Desa Pulosari Kebakkramat Kecamatan Kebakkramat Kabupaten Karanganyar (Doctoral dissertation, Universitas Muhammadiyah Surakarta).

Umar, F. S. (2016). Sanitasi lingkungan yang buruk sebagai faktor risiko kejadian diare pada balita di wilayah kerja puskesmas Kedaton Kecamatan Kedaton Kota Bandar Lampung.

Umiati, U. (2010). Hubungan antara sanitasi lingkungan dengan kejadian diare pada balita di wilayah kerja puskesmas Nogosari Kabupaten Boyolali Tahun 2009 (Doctoral dissertation, Universitas Muhammadiyah Surakarta).

United Nations Children's Fund .(2016). One is too Many: Ending Child Deaths from Pneumonia and Diarrhea. New York: UNICEF. Diakses dari: $\quad$ https://data.unicef.org/wpcontent/uploads/2016/11/UNICEF-PneumoniaDiarrhoea-report2016-web-version.pdf

Wandansari, A. P. (2013). Kualitas sumber air minum dan pemanfaatan jamban keluarga dengan kejadian diare. KEMAS: Jurnal Kesehatan Masyarakat, 9(1), 24-29.
Wibisono, A. F. (2014). Sosialisasi bahaya membuang sampah sembarangan dan menentukan lokasi tpa di Dusun Deles Desa Jagonayan Kecamatan Ngablak. Asian Journal of Innovation and Entrepreneurship, 3(01), 2127.

World Health Organization. (2011). Water, sanitation and hygiene interventions and the prevention of Diarrhoea. Diunduh tanggal $4 \mathrm{Mei}$ $2019 . \quad$ tersedia dari https://www.who.int/elena/titles/bbc/wsh_diarrh oea/en/.

World Health Organization.(2017). Progress on drinking water, sanitation and hygiene : 2017. Update and sdg baseline. New york and geneva: WHO \& UNICEF. Diakses dari: https://www.unicef.org/publications/index_9661 1.html

Zulkibli, Z. (2007). Hubungan cakupan air bersih dan jamban keluarga dengan prevalensi diare di kabupaten sambas tahun 2006 (Doctoral dissertation, Diponegoro University).

Retno Arienta Sari ${ }^{*}$ Mahasiswa Fakultas Kedokteran Universitas Lampung. *Email: retnoarientaar@gmail.com Dyah Wulan Sumekar Rengganis Wardani ${ }^{2}$ Departemen Ilmu Kedokteran Keluarga, 